\title{
'The Evangelisation of the Nation, the Revitalisation of the Church and the Transformation of Society': Megachurches and Social Engagement
}

\author{
Andrew Davies
}

\section{1 \\ Introduction}

By common scholarly consent, Pentecostals have never been particularly engaged social or politically (Anderson 2012; Chong 2015: 219; Davies 2018a; Davies 2019). ${ }^{1}$ It was not that they were uncaring or uninterested. It did not take the early Pentecostals long to confront the social challenges faced by their communities, even if in small ways, through the establishment of care homes, orphanages and feeding programmes (Kay 2009: 302; Wilson 2011:12). Yet they were too focussed on their hope for the ultimate (as far as they were concerned, impending) resolution of eternity to be too deeply and systematically concerned with the hardships faced in the here and now, even when these were hardships that were faced by their own community as much as by any other. Furthermore, they appear to have been concerned that engagement with any sort of 'social gospel' would distract them from their central call to preach the 'full gospel' of individual transformation through faith in the saving death and resurrection of Jesus Christ. Undoubtedly, the priority of the earliest Pentecostals was "saving souls rather than changing socio-economic and political structures" (Hunt 2011: 157), and they were so committed to individual transformation that systemic change never became a priority for them (Prakash 2010).

But, as time passed and the movement grew, Pentecostals found "such strong solidarity among themselves, courageously going against social norms such as racial segregation, that they forged a social and spiritual culture

1 I am indebted to my colleague Grace Milton for her invaluable support with the initial research for this chapter. 
where the hopeless found a space to experience God's grace and power" (Ma 2009: 42), and that space simply had to grow outward. As Gros observes, Pentecostalism, though it did not possess a social programme, became itself a social programme (Gros 1987:12). Their dynamic and entrepreneurial approach to life in general, their distinctive commitment and connection to the poor and downtrodden in society and their innate skill in gathering them, motivating them and releasing them into activism meant that when the Pentecostals did more consciously turn their attention to building a better world, they approached the task with dedication and vigour, and to dramatic effect. By the turn of the millennium, we saw the rise of 'progressive Pentecostals', a new kind of "Christians who claim to be inspired by the Holy Spirit and the life of Jesus and seek to holistically address the spiritual, physical, and social needs of people in their community" (Miller and Yamamori 2007: 2). The engine room of the Christian quest for social transformation had moved to the Global South and to the Pentecostals. And whilst they are very actively present in much smaller churches too (Miller and Yamamori 2007: 135), many of those sociallyengaged 'progressive Pentecostals' can today be found in the world's largest megachurches, which in many quarters now embrace the social gospel with as much energy as their antecedents had denounced it just a couple of generations before.

Of course, by no means all megachurches are Pentecostal, even by the broadest definition. There are a handful of 'progressive' megachurches, one very notable example being All Saints Episcopal Church, Pasadena, California, ${ }^{2}$ with its long tradition of social concern, rights advocacy and political campaigning. And there are lots of megachurches which are solidly Evangelical and equally firmly not Pentecostal, such as the smaller of London's two Anglican megachurches, All Souls Langham Place. But if a megachurch is rightly to be defined by its culture, its style and its theology as well as its attendance (cf. Chong 2015: 216; Niemandt and Lee 2015; Thumma 2012) then perhaps it is inevitable that there will be a significant amount of overlap between the Pentecostals/Charismatics and the megachurches ecclesiologically. I suggest there are also strong connections between Pentecostal/Charismatic and megachurch notions of social justice and transformation, and that ongoing evolution of each movement's perspective has reinforced and sustained emerging change in the other's. It is doubtful the megachurch movement would exist in its current form without Pentecostalism, but equally I suspect the 'progressive

2 https://allsaints-pas.org. 
Pentecostals' would not have sought to pursue their transformative influence so extensively had they not seen the megachurches supporting this new agenda, sustaining and propagating it more widely through their collaborations, conferences and events, and consistently forging new pathways for others to follow by drawing upon the imagination and innovation that has long been a distinctive of Pentecostalism (Petersen 2013: 51). As we will see, many of these megachurches are now using that influence to immensely positive effect across the world, drawing upon their own distinctive approaches in contextually-appropriate ways to address the needs that are common to all humanity.

Socially-engaged megachurches understand their social concern activity to be a fundamental part of their commitment to be missional expressions of Christian community at the heart of society. Holy Trinity Brompton (нтв) offers an excellent practical demonstration of this ideology in practice. Its vision, "to play our part in the evangelisation of the nation, the revitalisation of the church and the transformation of society" sounds at first as if the church sees itself as possessing three, albeit related, responsibilities, but actually the church sees the three clauses not only as indivisible and indistinguishable, but actually as amounting simply to different ways of phrasing the same core pursuit. As far as нтв are concerned, evangelisation, revitalisation and transformation are three 'modes' of the same unified mission rather than distinct personae. That mindset undoubtedly, and extensively, shapes the character and form of the church's social engagement, which for them is not an optional, supplementary concern, but is rather, to continue the trinitarian allusion, its very essence and source of being. For нтв, a revitalised church must, as its natural outcome, proclaim the gospel (through evangelism) and live it out (through social transformation) and the resulting spiritual growth must always both promote and result in human flourishing, thereby building stronger communities and making the world a better place for all its citizens. If that is the case, then, what are the megachurches doing to help deliver this world?

\section{Megachurches and Social Engagement}

\subsection{Confronting Poverty in the West}

If there is any element of commonality to the Western megachurches' social engagement strategies, it is that the vast majority of them offer a variety of activities seeking to improve the life circumstances of individuals in poverty 
in their own community and, often, in other corners of the world, seeking in a variety of ways to address the "embedded sense of powerlessness" among the poor (Myers 2015: 117). The five London congregations we studied as part of the University of Birmingham's Megachurches and Social Engagement in London research project from $2013^{-16^{3}}$ all pursued such ministries, with feeding projects and initiatives for rough sleepers and the homeless such as touring medical and hygiene facilities, soup kitchens, short-term shelters, street work and hostel services being particularly important for them. New Wine Church in Woolwich, London, provides a free breakfast every Saturday for the underprivileged of the local community and invites them to stay, if they wish, for a short service (just about all of them do). Manchester, England's 5,000-member !Audacious Church ${ }^{4}$ provides free lunches for school children from poorer backgrounds during the long summer holidays, and is one of a few British churches (also including New Wine and Kingsway International Christian Centre) that collect and deliver Christmas food and gift hampers for underprivileged families in their area. In Sweden, Uppsala's Livets Ord (Living Word) Church runs its own hostel for the homeless and works closely with local police and civic authorities to offer a Nattvandring or 'night patrol' service to look out for those in need on the city streets ${ }^{5}$ whilst Ukraine's Embassy of the Blessed Kingdom of God for all Nations not only feeds the hungry but seeks to teach healthy living and eating to its congregation members. ${ }^{6}$

Poverty relief activities were also a prominent focus of the megachurches featured in Omri Elisha's study in Knoxville, Tennessee, where he notes the commitment of what he labels "socially engaged evangelicals" to supporting "local populations such as the urban poor, the homeless, racial and ethnic minorities, and the sick and elderly ... [by] volunteering at soup kitchens and crisis shelters, mentoring inner-city youths, sponsoring immigrant refugee families, and providing charitable assistance to health clinics and halfway houses" (Elisha 2011: 8). Indeed, similar activities appear to be very common among the US megachurches. Lakewood Church, Houston, Texas, may have endured harsh criticism over its perceived slowness to respond to the Hurricane

3 Holy Trinity, Brompton (or HTB as it is popularly known, www.htb.org), Jesus House (www .jesushouse.org.uk), New Wine Church Woolwich (www.newwine.co.uk), Kingsway Interna; tional Christian Centre (www.kicc.org.uk) and (the only non-Pentecostal/Charismatic megat church in our study, and indeed in the UK) All Souls, Langham Place (www.allsouls.org).

4 http://audaciouschurch.com.

5 https://www.livetsord.se/uppsala/socialt-humanitart-arbete/.

6 http://godembassy.com/blog/healthy-lifestyle/. 
Harvey crisis (An 2017; Dart 2017), arguably unfairly, but has since been publicly honoured by the city's mayor for its 'Hope for Houston' and 'Servolution' programmes, which include relief and rebuilding projects in hurricane-damaged districts as well as its 'Beacon Center' daycare facility for the homeless and its food bank. ${ }^{7}$ The usA's other largest churches all have their own equivalent programmes. Willow Creek Community Church, South Barrington, Illinois has its 'Care Center' which provides free optometric and dental services as well as clothing and grocery banks, and an innovative automotive service, C.A.R.S., which "provides reliable transportation to those in need through refurbished, donated vehicles with the help of volunteer mechanics". ${ }^{8}$ Care ministries at Californian multi-site Saddleback Church ${ }^{9}$ include hospital visitation programmes, support for those with mental health, career and financial and addiction difficulties, and even a weight loss and healthy lifestyle programme, the 'Daniel Plan'. ${ }^{10}$ Bethel Church, Redding, California ${ }^{11}$ and Potters House, Dallas, Texas ${ }^{12}$ also promote a wide portfolio of social care ministries. Such services are not restricted to purely physical locations, either; the translocal reach of the megachurches and their 'soft power' influence through traditional and social media mean that even their websites provide important resources for their communities (Martin et al. 2011), with America's many Black megachurches being viewed by statutory authorities as critically-important routes for focussed messaging on healthcare to African Americans (Campbell and Wallace 2015).

Outside the USA, one of the longest-established and most comprehensive megachurch social concern programmes is that offered out of 38,000 member Sydney-based Hillsong Church. Its CityCare programme ${ }^{13}$ was established in 1986, only three years after the founding of the church, and offers a wide range variety of community services, including advocacy and personal development programmes; counselling services (with professional as well as volunteer staff) and a health centre; a variety of teams supporting the homeless, visiting nursing homes, prisons and immigration detention centres; a variety of children's and youth activities including mentoring opportunities and 'strengthening

\footnotetext{
7 https://www.lakewoodchurch.com/Pages/Ministry.aspx.

8 https://www.willowcreek.org/en/locations/care-center.

9 https://saddleback.com.

10 https://saddleback.com/connect/ministry/the-daniel-plan.

11 http://bethelredding.com.

12 https://thepottershouse.org.

13 http://hillsong.com/citycare.
} 
families' playgroups. CityCare's Justice Projects gather short-term teams to deliver "large-scale practical assistance" on projects such as "high school renovations, suburb graffiti blitz and many home renovations for families in desperate need of assistance", ${ }^{14}$ whilst the church also has special ministries working on providing crisis care as well as special feeding and food donation programmes around Easter and Christmas. ${ }^{15}$ Hillsong's 'Sisterhood' women's ministry holds regular 'Be the Change' mornings, where they have taken part in activities such as putting together 'Bravery Bead Bags' and crocheting headbands for children in chemotherapy, knitting blankets and teddy bears for children in the emergency ward, undertaking home renovation/makeover projects for underprivileged families, packing food hampers and 'care packages' for local businesses, and many other activities (Riches 2017). As a truly global megachurch, too, Hillsong also works alongside a variety of partner organisations across its international congregations on large-scale systemic global social challenges, including tackling modern slavery in conjunction with A21; ${ }^{16}$ working with street children and other vulnerable people in Mumbai with Vision Rescue $^{17}$ and supporting vulnerable children worldwide through Compas$\operatorname{sion}^{18}$ and the Watoto programme. ${ }^{19}$ Hillsong has also worked across all its international locations to address the Syrian refugee crisis in conjunction with World Vision. ${ }^{20}$ Such an extensive portfolio and the church's global recognition both bring their challenges; Parkes suggests that the church's "global profile" has perhaps "necessitated its interface with ethical issues that it is not theologically prepared for", and this means that the church has to find itself in "a constant process of reimagining its approach to social engagement and ethical issues and demonstrates increasing energy for community mobilization" (Parkes 2017: 235), but it has managed to approach such challenges with a fair degree of reflexivity and creativity on the basis of a solid theological foundation (Davies 2017).

Though Hillsong's global programme is particularly extensive, many other Western congregations prioritise the alleviation of global poverty as a central

\footnotetext{
14 http://hillsong.com/citycare/justice-projects/.

15 cf. http://hillsong.com/citycare/kilo-of-kindness/ and http://hillsong.com/citycare/ stuffthebus/.

16 http://www.a21.org.

17 http://visionrescue.co.in, cf. http://hillsong.com/bwc/vision-rescue/.

18 http://www.compassion.com.au.

19 http://hillsong.com/bwc/watoto/.

20 http://hillsong.com/bwc/refugee-response/.
} 
focus of their social concern ministries, too, with one excellent example being 6,ooo member City Impact Church in Auckland, New Zealand, which promotes child sponsorship, support for those with disabilities, and development and aid work extensively as part of its international missions outreach. ${ }^{21}$

\subsection{Confronting Poverty in the Global South}

The pattern of activity around poverty relief in megachurches across the majority world is not hugely different either, except perhaps with additional emphasis on healthcare and special provision for children and for elders. Asia presents some excellent examples here. The 75,000 member Onnuri (All Nations) Community Church in Seoul, South Korea (en.onnuri.org/aboutonnuri/onnuris-vision/) has a special ministry programme for the poor neighbourhoods of the city and the outlying fishing and farming villages, to tackle social exclusion and poverty there, and also hosts a variety of weekly special worship gatherings for those with learning difficulties, ${ }^{22}$ a ministry which is also a special concern of City Harvest Church, Singapore (Chan 2017: 298). The world's largest congregation, 480,0oo-member Yoido Full Gospel Church in Seoul ${ }^{23}$ needs a separate ten-storey building to house its welfare division, which incorporates a health clinic, a medical mission unit and a hospice, a development department with its own specialist security team and a procurement division. Yoido also hosts an extensive ministry to North Korean refugees and "provides vocational and spiritual training for unemployed youth ... apartments for homeless senior citizens and cares for neighbourhoods in poor environments" through its Elim Welfare Town (cf. Anderson 2012: 163165). In Indonesia, Bethany Church, Surabaya (with some 70,00o members) ${ }^{24}$ offers a variety of clinic and health programmes through its Bethany Care agency. At the opposite end of the megachurch scale, the 2,500 member New Hope Power Assemblies of God Church in Madurai, Tamil Nadu, India, has recently introduced a free ambulance service to provide first response at accidentsites. $^{25}$

The South American context is slightly different, however. In Santiago, Chile's largest church, Catedral Evangelica de Jotabeche Chile delivers much of

\footnotetext{
21 https://cityimpactchurch.com/about-city-impact-church/outreach-and-missions/.

22 http://en.onnuri.org/ministries/handicapped/.

23 http://www.fgtv.com.

24 http://bethanygraha.org/id/.

25 https://johnarulministries.com/ministries.php.
} 
its social engagement work through its 'Dorcas Team' ('el Cuerpo de Dorcas'), a women's ministry programme named in tribute to the Dorcas of Acts 9:36, a woman who was "committed to social work, making dresses and robes for widows and the dispossessed" ("una persona que se dedicaba a las labores sociales, preparando vestidos y túnicas para las viudas y los más desposeídos"). ${ }^{26}$ The Dorcas Team is overseen by the senior pastor's wife and seeks to provide spiritual as well as material assistance for those in need, with its first priority being identified as prayer for those in need. The 15,000-member Iglesia Rey de Reyes (King of Kings Church) in Buenos Aires has for the last few years organised an annual Operación Vida ('Operation Life') social and evangelistic event in different regions of Argentina. In 2016 this programme gathered a thousand volunteers from the church and other more local congregations in Concordia, Entre Ríos to collaborate on a remarkable five-day social concern campaign, during which they worked with 4,00o families, two hospitals, four schools, two prisons across thirty areas of the city, providing food, clothing, medicine and healthcare support before concluding the week with a huge stadium 'night of salvation' evangelistic rally at which "thousands accepted Jesus into their hearts". ${ }^{27}$

On the whole, though, it is striking how the South American megachurches consistently provide comparatively little detail of their social engagement programmes on their websites. There may be both cultural, practical and theological explanations for this. Perhaps the social engagement priorities of churches on this continent are slightly less explicitly focussed on charitable approaches to the resolution of poverty, or perhaps the churches are simply less comfortable in promoting such ministries. It may also be that the 'cell church' model so prominent across the region means that active compassion for the poor is a function of the small groups which comprise the church more than of its wider organisation. Köhrsen (2015) suggests social class may also be a factor, noting an interesting distinction between the 'lower class' churches which attract members from the more deprived communities and which prefer to emphasise the spiritual practices they believe will bring deliverance from the challenges of life (such as prayer, healing and exorcism) rather more than economic or social intervention, and the more socially liberal middle class congregations, which focus more extensively on influence, commercial opportunities

26 https://www.jotabeche.org/dorcas/.

27 'Vivimos una noche de Salvación donde miles aceptaron a Jesús en su corazón', http:// www.claudiofreidzon.com. 
and business success. It is entirely possible that systematic approaches to poverty relief in practical ways fall between these two ideological stools.

Köhrsen also observes, however, that by comparison with Latin America in particular, African Pentecostals have tended to be much more comfortable with publicly tackling humanitarian and development challenges, noting too that one of the distinctive features of Africa social engagement is caring for HIV/Aids patients, given the extent of that epidemic across the continent. Certainly the public social engagement profile of, for example, Rhema Church, Johannesburg, South Africa, which provides soup kitchens, health care, disaster relief and emergency accommodation through its Hands of Compassion programme, established in $1987,{ }^{28}$ is very different from that of South America's largest churches, and much more communitarian in focus than similar Western projects. Watoto Church, Kampala Uganda, sets out its mission as being "to serve the community holistically - spirit, soul and body" and is especially notable for its commitment to environmental and economic sustainability across all its projects. ${ }^{29}$ As well as promoting its internationally-famous children's choirs, Watoto creates eco-friendly orphanage-villages for vulnerable children in traditional African community style, inviting members to commit to regularly visiting the villages to help bring up and socialise the children in the hope of creating as much of a traditional family environment for them as possible, ${ }^{30}$ and have extensive programmes around trauma rehabilitation, adult literacy and business training as well as HIV/Aids care. ${ }^{31}$ Meanwhile International Central Gospel Church, Accra, Ghana, has its own fully-fledged development programme, Central Aid, which highlights the church's "divine mandate and responsibility to demonstrate the wisdom and creativity of God in providing solutions to the issues of poverty, deprivation, ignorance and diseases plaguing humanity". ${ }^{32}$ Africa's great need in some of these areas has certainly resulted in some innovative practice from its megachurches.

\subsection{Beyond Poverty: Other Social Engagement Strategies}

The above whistle-stop global tour highlights the huge variety of programmes by which the megachurches seek to relieve poverty in their own communities and sometimes beyond, therefore, but for all the importance of this agenda,

\footnotetext{
28 http://www.rhema.co.za/hand-of-compassion.

29 https://www.watotochurch.com/index.php?id=11.

30 https://www.watoto.com/our-work/watoto-villages/.

31 https://www.watoto.com/our-work/neighbourhood.

32 http://www.centralaidgh.org.
} 
relief and development is in itself just one element of a broader commitment to social engagement. Many of the megachurches do much more than relieving physical need.

For example, first, there is, of course, a long-standing history of Christian involvement with education, training and personal and skills development, and this continues to this day in various forms, including formal theological education and vocational training as well as general schooling. So the 20,000-member Fraternidad Cristiana in Guatemala City has its own school, ${ }^{33}$ as does Bethany Church Surabaya. Yoido Full Gospel Church oversees both Hansei University in Seoul and Bethesda Christian University in Anaheim, California for Korean-speaking students based in, or wishing to study in, the US. In Peru, Lima's Comunidad Cristiana Agua Viva has a leadership school, as does Potter's House, Dallas. Calvary Temple, Hyderabad, India's biggest church which claims almost a quarter of a million members and attracts some 40,000 attenders to each service, runs its own Bible College, ${ }^{34}$ whilst Holy Trinity Brompton, London (нтв), has strong historic and ongoing connections to the multi-site theological seminary, St Mellitus College. ${ }^{35}$ London's Kingsway International Christian Centre (KICC) runs a ground-breaking access to higher education programme, 'Breaking Educational Barriers', which invites senior admissions tutors from leading global universities to talk to its young people about how to apply successfully for university admission, in the hope of them maximising their life opportunities. ${ }^{36}$

Second, increasingly, megachurches are finding themselves needing to support migrant and minority communities, working with refugees, on immigration, supporting transnational communities and confronting people trafficking. !Audacious Church, Manchester and All Souls Langham Place, London both work closely with the NGO Church Response for Refugees, ${ }^{37}$ whilst a number of the British-African megachurches such as KICC, Jesus House ${ }^{38}$ and Winners Chapel ${ }^{39}$ maintain strong links with networks, congregations and leaders back in Nigeria and Ghana especially and draw upon these resources to

33 http://liceofrater.edu.gt.

34 http://www.calvarytemple.in/calvary-bible-college/.

35 https://www.stmellitus.ac.uk/about-us/our-history.

36 https://www.kicc.org.uk/church/community-initiatives/.

37 https://www.forrefugees.uk/about-us/our-partners/.

38 http://www.jesushouse.org.uk/.

39 https://winners-chapel.org.uk/. 
promote business contacts and professional opportunities in both directions as well as to support new migrants to the UK.

Third, most of the Western megachurches at least also provide Counselling, Rehabilitation and Support Services, seeking to support their members and their wider communities through life challenges and challenges by the provision of services around child and elderly care, marriage and divorce, bereavement and grief support, mental health care and counselling more generally, and rehabilitation work with prisoners and (ex)addicts. Holy Trinity Brompton (нтв) in London, home of the renowned Alpha Course, and Saddleback Church in California both have extensive programmes in this space, and KICC has a 24-hour pastor-on-call service for emergency counselling. In many of the South American and African congregations, 'counselling' means meeting for prayer and deliverance ministry rather than for therapy, but this spiritual support is a service that is frequently offered. Brazil's Universal Church of the Kingdom of God offers an online help centre through its London congregation where visitors can seek assistance and can email in prayer requests. ${ }^{40}$

Finally, perhaps the most interesting range of projects, however, is the rather newer trend towards tackling the modern disease of social isolation through community-building, social participation and befriending programmes. Lim (2015) identifies this as an area in which the Singaporean megachurches have had particular success and to which they have a particular attraction, and wonders if such programmes are the Singaporean churches' conscious or unconscious demonstration to a slightly sceptical government that the advance of Christianity poses no threat to national cohesion, but rather an opportunity for extending social and civic harmony. Certainly the variety of friendship and community-building projects offered by Singapore's megachurches is impressive; Chan (2017: 293-94) observes that in 2013, just one of these churches, City Harvest Church, administered over 130 different projects, which range from offering home and hospital visits to the city's elderly poor to a dance and performing arts school for high school students, and highlights City Harvest's commitment to holistic ministry, support for the whole person across all the ages of life, through the provision of both explicitly religious and absolutely non-religious services. City Harvest has consciously sought to use contemporary pop culture in its quest to engage with the everyday lives of its younger attenders, and for that matter to 'redeem' that culture by imbuing it with 
Christian values (Chan 2017: 295). Similarly, Hillsong London also features a 'community youth' arm it labels 'iCareRevolution', ${ }^{11}$ which it describes as helping to "release the unique potential inside every young person by offering practical help with the issues that every young person faces every day of their life ... changing the mind-sets of London's youth by encouraging them to be the difference ... telling the kids that they are not worthless and that they have a future no matter where they come from or what their background is". ${ }^{42}$ Care for the elderly is not neglected either, with an extensive range of projects including monthly lunch clubs, summer and Christmas parties and 'adopt a granny/ grandad' programmes highlighted under the 'Regenerate RISE' banner. ${ }^{43}$ For the Hillsong 'mother church' in Sydney, engagement with issues around mental health and wellbeing and active participation in NAIDOC week, which celebrates the role of Aboriginal and Islander peoples in modern Australia, have been among more recent interventions.

The value of these kind of contributions to the life of megachurch members and non-members is inestimable. The most obvious contribution, perhaps, is relational, in terms of the supportive networks of friendship they provide, helping people to connect with others in cities that are often isolating, and shaping the way people choose careers, develop friendships, relate to their neighbours, conduct their relationships and family lives, look after their health, use their money, or get involved in politics, charity work or campaigning, locally, nationally and globally. Naturally the megachurches wish, and seek, to see their members use those resources for the good of the church as well as the community. But in return they also make a significant investment into their members' own individual social capital.

In any truly global megacity such as London, the role of the church in supporting the integration of immigrant communities cannot be overvalued. One of the reasons for the success of London's African-led megachurches appears to be the support they provide for newcomers to the UK in offering them a reminder of home and the promise of a new community. But the phenomenon is rather wider than that. Because of London's black megachurches, the doctor just moved over from Nigeria to work in one of the capital's big teaching hospitals gets an instant family who understand the challenges she will be facing in coming to terms with British society, culture and environment, and quite

\footnotetext{
41 http://icarerevolution.co.uk.

42 http://hillsong.com/uk/bwc/icarerevolution.

43 http://hillsong.com/uk/bwc/the-platt-centre/.
} 
possibly know her home region, if not city; a new network of friends who share her core beliefs and values and understand her needs; and a concrete link to and a positive reminder of home in her new church's exuberant worship (which, in the black churches at least, quite probably reflects African musical styles and may sometimes even be sung in her native language). But she is not the only one whose life is positively transformed by engaging with the megachurch. For the elderly widower living a lonely and isolated existence in his sheltered cul-de-sac, the weekly luncheon club might be quite literally a lifesaver, and attending church services might offer the only significant engagement with other people that he gets all week. Because of the megachurch, the teenager from the tower block has a group of friends who are like him, who respect and value him and mean that he no longer needs to seek that status in a street gang; whilst his older sister learns that she can accomplish more than society has ever told her is possible and encouraged to aspire to the very best future imaginable - a top university, a great career, a prosperous and fulfilling life. The immense contribution that the churches make to thousands of such lives across the world's great cities cannot be ignored socially, or indeed economically.

\subsection{Megachurches' Political Engagement and Cultural Influence}

Given such a diverse and wide-ranging portfolio of activities worldwide, it is clear that the megachurches do a huge amount to positively impact society. But it is also noteworthy that just about all the interventions above seek to address individual outcomes, ameliorate individual circumstances, rather than deliver systemic changes. The megachurches are by and large treating the symptoms of social deficit and not its causes. For example, perhaps we sometimes failed to ask the right questions, but in our study of London's black megachurches, the issue of racial justice was never once raised with us. There was plenty of talk about advancement, opportunity and achievement, but this was always in the context of each individual taking personal responsibility for living God-honouring lives. Racism, social deprivation and oppressive societal structures were never raised with us as challenges. There is more than anecdotal evidence to suggest that this is a more global phenomenon, too; one recent study of the priorities of mission programmes across over 450 US megachurches showed that racial reconciliation, AIDS, and social justice fell a long way down the list of priorities (with interreligious relations and environmental concerns propping up the table) (Priest et al. 2010). And there are quite probably ideological motivations behind this. As Anderson notes, "Pentecostals have traditionally been opposed to political involvement ... [and] have been 
accused of an otherworldly spirituality that avoids 'worldly' issues like politics and the struggle for liberation and justice, and of being guilty of proclaiming a gospel that either spiritualizes or individualizes social problems" (Anderson 2012: 153). It seems to me that the megachurches have, for good or ill, most frequently gone down a similar path. The long and short of it, for good or ill, is that "while social engagement has often been inspired by evangelical renewal, the search for personal transformation and for authentic faith has always been the central impulse of evangelicalism" (Carpenter 2013: 265).

There are exceptions and qualifications to such a claim. Reynolds and Offutt point to the development strategy adopted in the last few years by Rick Warren at Saddleback Church as "borrow[ing] heavily from ideas of transformational development and holistic mission", but claim that even this programme possesses "a less developed theological framework concerning the structural and relational forces contributing to poverty" than most freestanding faith-based development NGOS (Reynolds and Offutt 2013: 253-254). Yet most megachurches adopt significantly more individualistically-focussed strategies than Saddleback. Europe's largest churches have on the whole actively tried to distance themselves from party politics. In London, both All Souls and нтв have a number of members who are politically active and who hold elected office, and both churches will regularly publicly pray for and commend them, but stay well out of the way of party politics at election times. Whilst they seek to maintain good relationships with local elected leaders, any sort of endorsement or public acclamation would be out of the question. And, on the whole, Asian megachurches have followed a similar path, though it is worth remembering that the political campaigns and street protests that led to the democratisation of South Korea in 1987 were actively supported by Pentecostals and Evangelicals (Chong and Goh 2014: 413). Terence Chong argues though that the apolitical approach adopted by Singaporean megachurches has been a conscious strategy to avoid conflict with the state, suggesting that a central part of their success has been because "local megachurches have learned to dedicate resources to welfare needs without being critical of the very capitalist ethos which perpetuates these needs. Unlike liberal Christianity, megachurches disentangled political activism from social action" (Chong 2015: 218).

Given the long (and arguably somewhat murky) history of Evangelical engagement with politics in the USA, we might have expected rather more political engagement from the North American megachurches, but here too, there is some evidence of increasing caution. One study from Campbell and Putnam (2012) identified a significant fall in the proportion of sermons having explicitly political content from 2006 to 2011, leading them to conclude Americans 
were moving toward a "growing aversion to blurring the lines between God and Caesar" and noting "if clergy continue to retreat from politics, candidates of the religious right will have fewer opportunities to tap into church-based social networks for political mobilization".

On the latter suggestion at least, the 2016 presidential election proved them to be in error. President Trump swept to power with the votes of over 80 percent of white evangelicals (Smith and Martínez 2016), and his evangelical advisory council included a number of megachurch pastors, many of them initially attracted to supporting him because of his perspectives on religious freedom. A number of them, too, have since felt obliged to speak out against some of Trump's policies (Maza 2018), but the general position of at least the white megachurch leaders has remained at very least sympathetic.

Black and Latina/o leaders have certainly been more sceptical, but not generally too much more vocal. Indeed, it has been alleged that "the preoccupation of Black churches with 'prosperity gospels', color-blind theologies, and a strong focus on its communal and priestly functions has largely inhibited faithbased political action" (House 2018: 15; cf. Tucker-Worgs 2011). However, Bishop T.D.Jakes of Potter's House, Dallas, perhaps America's leading African-American pastor, is one who has been sharply critical of Trump's policies on immigration (Jakes and Hill 2018) and indeed of fellow Evangelicals for their uncritical acceptance of the administration's agenda ("I'm afraid that the church is compromising its integrity for the benefit of photo-ops at the White House", Jakes and Hill 2018). It is sometimes suggested that the increasing proportion of middle class, educationally-qualified African-Americans and their sense of aspiration and hope have resulted in a generation who are more comfortable with the prosperity teaching of the black megachurches and are therefore equally comfortable with attending them (Benson 2011: 28), but it seems to me the causality might just run in the opposite direction. Even if the megachurches perhaps fail to confront injustice as publicly as they might, they certainly encourage aspiration, hope and opportunity.

Maybe some of their members are enticed to make something more of their life because of the megachurches' ministry. And whilst the leaders of America's black megachurches generally do eschew political campaigning, their preaching certainly emphasises themes of social concern and mobility, and in particular feeds personal and community empowerment. They seek to build community prosperity 'from the bottom up', by empowering individuals to change their world, impact those around them and then work together to change society (cf Algranti 2012; Barnes 2011). 
There are two continents, however, where megachurches have adopted a much more positive perspective on politics. In both Africa and South America, megachurches and megachurch leaders have been very actively engaged in electoral politics. Hunt observes "Pentecostalism's proliferating involvement in a range of political processes and penetrating social activity has been evidenced in various parts of the world", adding that particularly in Latin America, "Pentecostals now stride the political landscape, increasingly abandoning their quietism to partake of orchestrated activity as they mobilize themselves for extending electoral opportunities" (Hunt 2011: 157). Such engagement has led to the creation of political parties in Colombia, Venezuela and Nicaragua in particular (Kim and Kim 2008: 169), and varying degrees of electoral success in Argentina and Brazil (Wilson 2011: 26), but it is at least arguably the case that ultimately such engagement has proven problematic for the megachurches. Algranti (2012) argues that for all their influence on their members, the Argentinian megachurches have singularly failed to shape national political life, and, indeed, that their leadership has become better trained, better qualified and better able to present themselves on the public stage and develop their own platform, they have distanced themselves from the community that they lead, resulting in a fair measure of conflict between church leaders and Evangelical politicians who both claim to speak for the community that neither groups now adequately reflect. This has led to a desire for churches to build influence in all spheres of society and encourage their members to engage with public life in all its fullness and aspire to leadership opportunities in other fields. Churches such as Mision Carismatica Internacional in Bogota, Colombia highlights the social significance of the church in its publicity, urge their members to take responsibility for growing into leadership roles across the arts, media and in business as well as in government. ${ }^{44}$

The challenge in Africa, as outlined comprehensively in the Nigerian and Zambian contexts by Burgess (2015), has resulted in similarly complex and contentious outcomes. Whilst megachurch and denominational leaders may feel they have preserved their religious freedom and pursued public benefit by seeking elected office, it is difficult to argue that their contribution has been unambiguously positive. Little wonder that, as Adekoya notes, "there are those who would want the Church to keep out of politics" in Nigeria (2018: 50).

http://mci12.com/blog/2018/07/o3/verdaderos-reformadores/. 
All this said, in many ways, it is not so much what the megachurches actually do that is of interest by way of comparison with smaller churches, but how and why they do it. Even a tiny village church can invest in international development ministry, given our globalised, connected world, and provide social support for the needy of its community (and many of them arguably engage a rather higher proportion of their attenders in such ministries, too). What sets the megachurches apart is the diversity and the scale of their offering and the sheer numbers they can engage with. Managing such a large and diverse portfolio of activities poses immense logistical challenges, but by definition the megachurches have the resources available to accommodate these. However, sometimes they do encounter challenges in aligning ministry and professional commitments. Some activities may invite legal complications, potentially significant financial risk to the church or reputational challenges. And in areas where external (secular) charitable or government money is available to support activity, there are always concerns from the donor side about appropriate alignment of religious and social objectives and the fear programmes might be used for proselytisation, and nervousness from the megachurch side that external funding might restrict their freedom to be explicitly Christian in their activity even though they seek to be wholly inclusives and shun any sort of religious test before or after providing assistance. Not least for such reasons, many of the megachurches set up separate agencies to deliver the work for them. So !Audacious Church, Manchester, routes most of its programmes through its !Audacious Foundation. New Hope Power Church, Madurai, focusses its social care work through an NGO founded by the senior pastor, Love and Care International, which cares for around 1,00o orphans and also runs infrastructure and development projects in some of the slum areas. ${ }^{45}$ Yoido Full Gospel church separates out its relief and development work out into two separate NGOs, the Elim Welfare Town and 'Good People World Family', ${ }^{4}$ which works on healthcare, education, development, emergency relief and child protection internationally and on child support and medical care and relief for North Korean refugees more locally in Korea. Singapore's City Harvest Church too "maintains a distance between its welfare ministries and politics

45 https://johnarulministries.com/ministries.php.

46 http://eng.goodpeople.or.kr. 
through the learned behaviour of privatization and compartmentalization" (Chong 2015: 235).

Other churches seek to work collaboratively across sector on development projects, with some of the more creative work here including partnerships with "state agencies and private nonprofits on urban community development initiatives and other social enterprises" (Elisha 2011: 8). Indeed, much of the American Evangelical contribution to global development and poverty relief is the result of systematic collaboration, often delivered through parachurch organisations which also retain a campaigning as well as a delivery role (Reynolds and Offutt 2013). Still, the economic costs of some of the activities undertaken are immense, and even with external financial support and collaboration, the success of most of the megachurches' most visible projects depends absolutely upon the generosity of church members in giving their finance and also their time to participate as volunteers in these programmes. It is interesting that the most prominent presentation of Lakewood Church's social engagement and concern programmes on its website is in the context of seeking volunteers to serve the church's vision, the community and ultimately God in participating in these activities, such as for example their 'rebuild mission' programme, where they ask members to take a week off work as 'staycation' to join a team working to rebuild flood-damaged communities. Willow Creek too extensively promotes its need for volunteers in specific areas ${ }^{47}$ and presents this as an important opportunity for all church attenders to make a genuine contribution to church life - clearly a practical challenge for a church with members in the tens of thousands. Hillsong Sydney offer some 40-50 different volunteering opportunities across the church in logistics, hospitality and administration as well as aid and care ministries, reminding its members that "Hillsong Church is not built on the gifts and talents of a few, but on the sacrifice of many". 48

Whilst one of the many attractions of megachurches in the West is sometimes (albeit somewhat sceptically) seen as being the opportunity to attend them with minimal commitment and remain distant and disengaged, that is not an approach that the churches encourage. For their own benefit as well as for the good of the individual members, the churches want to see all their attenders actively participating in the life of the church and actively engaged in ministry, and they seek to empower them to do this in a variety of ways.

47 https://www.willowcreek.org/en/serve.

48 https://hillsong.com/hills/volunteer/. 
As 6o,ooo member SaRang Church in Seoul puts it, the central call of any discipleship-focussed church is to 'awaken the laity' (Niemandt and Lee 2015: 4), and mobilising the people to meet the need has long been a strength of Pentecostalism (Ma 2009; Petersen 2013: 51). Volunteerism meets needs on many levels. Barnes (2011: 191-192) highlights the important contribution that qualified professional members can make as volunteers to support project delivery, citing one pastor who told her, "We have a lot of folks in the church who are professionals and they are very generous with their expertise. We help people directly with access to funds and then indirectly with information that will help them to live their life or break out of poverty ... as folks tithe to us $10 \%$ of their income, we tithe it right back out".

That empowering capacity is, furthermore, not restricted to activities delivered entirely by the church. Many individual members of megachurches are highly active in society in their own right and are actively involved in social engagement work of some kind outside of the church context, either as a volunteer, employee or trustee. Quite a few members have significant roles in local, regional and even national activities in this space. In our research in London, for example, we encountered senior civil servants, leaders of NGOs large and small, major charitable donors and major charity managers, medics, teachers, social workers, academics, counsellors and councillors of all hues, national politicians and a huge variety of other change agents sat in the pews. Many of them told us that their church's contribution to their lives was immense and a critical element of their support mechanism; and, indeed, that it was their religious commitment that motivated and sustained their professional responsibilities and their personal obligations. I would suggest that the contribution made by individual members of the megachurches probably outweighs the contribution made by the churches themselves, and a number of the church leaders we interviewed agreed.

Furthermore, many of those individual members were themselves responsible for initiating major projects in the churches. One of the key discoveries of our empirical work, for example, was that many of the projects we uncovered were not initiated by church leaders directly, but by members of the congregation who had been inspired by the preaching and culture of the church to be entrepreneurial and challenged by a particular social need to initiate activities themselves. Perhaps, therefore, one key insight is that megachurches succeed by creating the right environment for such activities to flourish and encouraging their members to 'step up to the mark' and lead in life as well as in the church. Members who have imbibed such attitudes cannot do anything 
other than respond to crisis needs because they have been trained to take responsibility for their own lives and commit to addressing the needs of others. Such activities are therefore as much church-initiated as anything the senior leaders themselves do, and are just as thoroughly integrated into the life of the churches and draw extensively on their values. Indeed, as Wilson observes, Pentecostalism's "principal focus" is "the development of human capital ... giving their converts a vision of what they and their societies could become", and seeking "to assist their own people in rising to the height of their spiritual, personal, and social potential". And as he continues, though this approach in the more explicitly religious context amounts to what we usually think of as evangelism, it "was not limited to the proclamation of the gospel. It was, in effect, a concerted effort to undertake social redemption from below" (Wilson 2011: 12). Human capital, then, is both the 'how' and the 'why' of megachurch social engagement; but there is value in unpacking the 'why' a little more extensively. Evidence suggests a variety of motivations feed into the social concern agenda - two of which are very much pragmatic and others which are rather more theological.

Practically, firstly, some of the megachurches' interventions are very clearly motivated by recognition of the social need of the church community itself because of its immediate need. Such commitments can arise from a sense of community or shared experience; Anderson notes that Yoido Church's commitment to confront poverty arises at least partially from the personal experience of its founder, David Yonggi Cho and that of the older generation of leaders in South Korea who still all too well remember the deprivation and economic collapse which surrounded the Korean War (Anderson 2012), whilst some of the younger leaders might relate to the challenges faced by rural to urban migrants (Chong and Goh 2014: 409). As the Korean churches preach God's blessing, their practical ministry also emphasises the role of God's people in bringing that blessing in concrete terms into the lives of their brothers and sisters in the church (and that is arguably very much a New Testament model). Second, there is the need of the surrounding community, which in itself is a call to action. It is sometimes said that Pentecostalism is a religion of the poor, not just for the poor (Ma 2009: 42). However it is also the religion of those who don't want to stay poor (Benson 2011; cf. Eagle 2015). At least to some extent, megachurches succeed because they present "the images (of the affluent lifestyle, contemporary relevance, and the created community) that prove the message of prosperity with the rest of the nation" (Carney 2012: 76); in Asia in particular, they represent the religion of the emerging middle class rather 
than the established middle class (Chong and Goh 2014: 410). In other words, megachurch leaders and members remember times when they have had to struggle too. Megachurch concern for the poor arises from identification with the poor and a recognition that much of the church's membership has come out from such contexts. As Kay (2009: 302) notes, their "activism and energy ... may be stimulated by the narratives of their own lives ... [they] feel empowered to the extent that they wish to tackle the most difficult social problems by the most direct methods".

The theological motivations which underpin megachurch social engagement, however, are multiple and varied. They act because "Christ's love compels them" (2 Corinthians 5:14); because Jesus himself cares for and deeply loves the poor, pointing to "Christ's early and continued involvement among the poor as an example of God's special love, value, and concern for them" and arguing "If living and serving among the poor was acceptable for Christ, committed Christians should be comfortable following suit" (Barnes 2011: 193). They act because they understand themselves as a family, and "Families take care of one another and celebrate together, and being part of a family is extremely healthy" (Alexander 2009: 148; cf. Chan 2017: 303; Chong 2015: 233). They act because they believe God himself is love, and because they believe that loving one another is the concrete, empirical demonstration of that love in a loveless world. As Guatemala's Fraternidad Cristiana expresses its mission:

We are characterized by love for God and for our neighbor. In the Frather regardless of our race or economic condition, we are all one in God. We are united by our faith and that is enough and it is enough. Inspired by the love of God, we reflect His love for others, by sharing our faith and helping each other to live it. ${ }^{49}$

They act, therefore, because to their mind there is an inherent and incontestable "link between Christian love, social action and eschatological hope" (Burgess 2009: 259). They also act because God has blessed them, and with that blessing comes the attendant responsibility of being a blessing to the world around, not least "by providing financial assistance to less-privileged believers and alleviating poverty in the wider society" (Burgess 2009: 258). They act because "the church is a sign of the kingdom of God and of the proleptic

http://frater.org/es/acerca-de/que-nos-caracteriza/. 
manifestation of God's reign, both in what it is and what it does", and where God reigns, his purpose is accomplished (Niemandt and Lee 2015:3).

They act because social engagement is for them fundamentally part of the task of mission and evangelism. In some ways, evangelism and social action are very clearly distinguished in the megachurches' thinking and strategy. They provide services to the community without as well as the community within, with no religious restrictions or obligations, free at the point of access and need. But they reject any assumption that there might be a difference between the preaching of the Gospel and its practice. For the megachurches, "Social action is mission" (Burgess 2009: 260). And as Elisha noted in his study of Knoxville's megachurches:

The tendency among many conservative Protestants to insist on a firm distinction between humanitarian effort and religious proselytization (privileging the latter) was rejected by those who favored a more integrative, holistic approach, the kind that prioritizes 'words and deeds' and regards both as equally crucial for effective evangelism among society's poor, distressed, and marginalized populations. Making the case for holistic evangelism in the evangelical churches of Knoxville - whether this meant arguing for broader conceptions of the church's role in society or simply arguing that, as one pastor put it, 'You can't talk to an empty stomach' - was a vital strategy by which the socially engaged evangelicals I observed appealed to their conservative base.

ELISHA 2011: 8-9

Here, then, in a sense, we find ourselves full circle, back where we started with the early Pentecostal rejection of an additional 'social gospel' being tagged on the end of the real thing, the 'full gospel', except this time, it is the 'real thing' that is in danger. For Elisha's 'socially engaged Evangelicals', any 'full gospel' expression of Christian mission which fails to make a practical difference on the ground for the poorest of the world fails to stand as a viable expression of God's grace in Christ. A gospel that isn't social is no gospel at all for the megachurches, who pursue social transformation on the basis of their theological obligations, and identify themselves as continuing a long tradition of Christian commitment to social change which can be traced back to heroic figures of earlier centuries such as Elisabeth Fry, William Wilberforce, Thomas and Syrie Barnardo, Robert Raikes, Martin Luther King, Mother Theresa, Lord Shaftesbury and William and Catherine Booth. They act because they have a story to continue and a world to keep transforming. They act because the need is still 
there. And, ultimately, as Hillsong Church explains, ${ }^{50}$ they act simply because they can.

\section{References}

Adekoya, R. 2018. "The Church as a Stakeholder in the Socio-political Development of Society: The Example of Nigeria." Journal of the European Pentecostal Theological Association. 38:1, 50-63.

Alexander, P. 2009. Signs and Wonders: Why Pentecostalism is the World's Fastest Growing Faith. San Francisco: Jossey-Bass.

Algranti, J. 2012. "Megachurches and the Problem of Leadership: An Analysis of the Encounter between the Evangelical World and Politics in Argentina." Religion, State and Society. 40:1, 49-68.

An, K. 2017. "Even if Joel Osteen did the right thing, he lost a chance to teach Christianity." USA Today, 2 September. https://eu.usatoday.com/story/opinion/2017/og/o2/ joel-osteen-right-close-lakewood-church-but-he-lost-chance-teach-christianitykirkland-an-column/622215001/.

Anderson, A. 2012. "A 'Time to Share Love': Global Pentecostalism and the Social Ministry of David Yonggi Cho." Journal of Pentecostal Theology. 21:1,152-167.

Barnes, S.L. 2011. "Black Megachurches: Social Gospel Usage and Community Empowerment." Journal of African American Studies. 15:2, 177-198.

Benson, D.A. 2011. "Black Religiosity: An Analysis of the Emergence and Growth of Black Megachurches." Unpublished MLS dissertation, University of Toledo.

Burgess, R. 2009. "African Pentecostal Spirituality and Civic Engagement: The Case of the Redeemed Christian Church of God in Britain." Journal of Beliefs \& Values. 30:3, $255^{-273}$.

Burgess, R. 2015 "Pentecostals and Politics in Nigeria and Zambia: An Historical Perspective." In M. Lindhart, ed, Pentecostalism in Africa: Presence and Impact of Pneumatic Christianity in Postcolonial Societies. Leiden, Brill, 291-321.

Campbell, A.D., and Wallace, G. 2015. "Black megachurch websites: An Assessment of Health Content for Congregations and Communities." Health Communication. 30:6, $557-565$.

Campbell, D.E., and Putnam, R.D. 2012. "God and Caesar in America: Why Mixing Religion and Politics is Bad for Both." Foreign Affairs. 91:2, 34-43.

Carney, C.R. 2012. "Lakewood Church and the Roots of the Megachurch Movement in the South." Southern Quarterly. 50:1, 61-78.

http://hillsong.com/bwc. 
Carpenter, J. 2013. "What's New about the New Evangelical Social Engagement?" In B. Steensland and P. Goff, eds, The New Evangelical Social Engagement. Oxford: Oxford University Press, 265-279.

Chan, K.-K. 2017. "City Harvest Church of Singapore: An Ecclesial Paradigm for Pentecostalism in the Postmodern World." In F. Yang, J.K.C. Tang and A.H. Anderson, eds, Global Chinese Pentecostal and Charismatic Christianity. Leiden: Brill, 286-308.

Chong, T. 2015. "Megachurches in Singapore: The Faith of an Emergent Middle Class." Pacific Affairs. 88:2, 215-235.

Chong, T. and Goh. D.P.S. 2014. "Asian Pentecostalism: Revivals, Megachurches, and Social Engagement." In B.S. Turner and O. Salemink, eds, Routledge Handbook of Religions in Asia. Oxford: Routledge, 402-417.

Dart, T. 2017. "Why did America's biggest megachurch take so long to shelter Harvey victims?" The Guardian, 30 August. https:/www.theguardian.com/us-news/2017/ aug/3o/lakewood-church-joel-osteen-hurricane-harvey.

Davies, A. 2017. "Because They Can: Hillsong and Social Transformation." In T. Riches and T. Wagner, eds, The Hillsong Movement Examined: You Call Me Out Upon the Waters. London: Palgrave Macmillan, 199-215.

Davies, A. 2018a. "Introduction: Pentecostals and Social Engagement." In Journal of the European Pentecostal Theological Association. 38:1, 1-2.

Davies, A. 2018b. "Reading Politics Through Scripture: International Relations, the Bible and Conservative Protestant Christianity." Journal of the European Pentecostal Theological Association. 38:1, 64-73.

Davies, A. 2019 (forthcoming). "Heritage and Hope: A Story of British Pentecostalism." In J. Aldred, ed, Pentecostals in Britain. London: SCM.

Eagle, D.E. 2015. "Supersized Christianity: The Origins and Consequences of Protestant Megachurches in America." Unpublished PhD Dissertation, Duke University.

Elisha, O. 2011. Moral Ambition. Berkeley: University of California Press.

Gros, J. 1987. "Confessing the Apostolic Faith from the Perspective of the Pentecostal Churches." Pneuma. 9:1 (Spring), 5-16.

House, C.A. 2018. "Crying for Justice: The \#BLACKLIVESMATTER Religious Rhetoric of Bishop T.D. Jakes." Southern Communication Journal. 83:1, 13-27.

Hunt, S. 2011. "Evaluating Prophetic Radicalism: The Nature of Pentecostal Politics in Brazil." In C.L. Smith, ed, Pentecostal Power: Expressions, Impact and Faith of Latin American Pentecostalism. Leiden: Brill, 157-177.

Jakes, T.D. and Hill, E. 2018. Interview: CNN New Day, 25 June 2018. http://transcripts. cnn.com/TRANSCRIPTS/1806/25/nday.o6.html.

Kay, W.K. 2009. Pentecostalism: SCM Core Text. London: SCM.

Kim, S. and Kirsteen K. 2008. Christianity as a World Religion. London: Continuum. 
Köhrsen, J. 2015. "Pentecostal Improvement Strategies: A Comparative Reading on African and South American Pentecostalism." In A. Heuser, ed, Pastures of Plenty: Tracing Religio-Scapes of Prosperity Gospel in Africa and Beyond. Frankfurt-amMain: Peter Lang, 49-64.

Lim, T. 2015. "Pentecostalism in Singapore and Malaysia: Past, Present, and Future." In Amos Yong, ed, Global Renewal Christianity: Spirit-Empowered Movements Past, Present, and Future. Lake Mary, FL: Charisma House, 126-135.

Ma, W. 20og. "When the Poor are Fired Up': The Role of Pneumatology in Pentecostal/ Charismatic Mission." In V-M. Kärkkäinen, ed, The Spirit in the World:Emerging Pentecostal Theologies in Global Contexts. Grand Rapids: Eerdmans, 40-52.

Martin, P., Bowles, T., Adkins, L. and M. Leach 2011. "Black Mega-Churches in the Internet Age: Exploring Theological Teachings and Social Outreach Efforts." Journal of African American Studies. 15:2, 155-176.

Maza, C. 2018. "Megachurch Pastor Slams Trump's Immigration Comments: Are Evangelicals Turning Their Backs On Trump?" Newsweek, 16/01/18. https://www.news week.com/church-megapastor-trump-immigration-evangelicals-shithole-782362.

Miller, D. and Yamamori, T. 2007. Global Pentecostalism: The New Face of Christian Social Engagement. Berkeley: University of California Press.

Myers, B.L. 2015. "Progressive Pentecostalism, Development, and Christian Development NGOs: A Challenge and an Opportunity." International Bulletin of Mission Research. 39:3, 115-120.

Niemandt, C.J.P., and Lee. Y. 2015. "A Korean Perspective on Megachurches as Missional Churches." Verbum et Ecclesia. 36:1, 1-8.

Parkes, C. 2017. "The Contours of Hillsong's Socio-Ethical Engagement." In T. Riches and T. Wagner, eds, The Hillsong Movement Examined: You Call Me Out Upon the Waters. London: Palgrave Macmillan, 235-252.

Petersen, D. 2013. “Three Challenges to Pentecostal Social Action." Asian Journal of Pentecostal Studies. 16:1, 51-60.

Prakash, D. 2010. "Toward a Theology of Social Concern: A Pentecostal Perspective.", Asian Journal of Pentecostal Studies, 13:1, 65-97.

Priest, R.J., Wilson, D. and A. Johnson. 2010. "U.S. Megachurches and New Patterns of Global Mission." International Bulletin of Mission Research. 34:2, 97-104.

Reynolds, A. and Offutt, S. 2013. "Global Poverty and Evangelical Action." In B. Steensland and P. Goff, eds, The New Evangelical Social Engagement. Oxford: Oxford University Press, 243-257.

Riches, T. 2017. "The Sisterhood: Hillsong in a Feminine Key." In T. Riches and T. Wagner, eds, The Hillsong Movement Examined: You Call Me Out Upon the Waters. London: Palgrave Macmillan, 85-106.

Smith, G.A. and Martínez, J. 2016. "How the faithful voted: A preliminary 2016 analysis." Pew Research Center. http://www.pewresearch.org/fact-tank/2016/11/og/how-the -faithful-voted-a-preliminary-2016-analysis/. 
Tucker-Worgs, T.N. 2011. The Black Megachurch: Theology, Gender, and the Politics of Public Engagement. Waco, TX: Baylor University Press.

Wilson, E.A. 2011. "Redemption from Below: The Emergence of the Latin American Popular Pentecostals." In C.L. Smith, ed, Pentecostal Power: Expressions, Impact and Faith of Latin American Pentecostalism. Leiden: Brill, 9-36.

Yong, A. 2010. "Pentecostalism and the Political—Trajectories in Its Second Century." Pneuma. 32:3, 333-336. 